\title{
$\bigcirc$ Škola a výchova v Německé demokratické republice
}

\section{Gert Geißler ${ }^{a}$}

a ve vzdělávání

Geissler@dipf.de

Received 5 November 2021

Accepted 15 December 2021

Available online 31 December 2021

DOI 10.15240/tul/006/2021-2-005
Abstract School and Education in German Democratic Republic

The German Democratic Republic, which emerged in 1949 from the eastern occupation zone in divided Germany, was the most western state in the Soviet sphere of influence. The article traces how a new, independent, and efficient school system emerged from a common German history. In constant political competition with the Federal Republic of Germany, it initially demonstrated a strong affinity with the Soviet school system, in which

educational practices were rooted in the doctrinal principles of a Marxist-Leninist pedagogy.

Keywords unified school, sovietisation and education, German history, Federal Republic of Germany, German Democratic Reublic, Marxist-Leninst pedagogy, educational science

\section{Výchozí stav}

Od počátku 20. století zaznívalo v Německu mezi částí učitelské obce a na politické scéně volání po ,jednotné škole“, která by napomohla $\mathrm{v}$ překlenutí stavovských a třídních rozdílů. Na všechny děti se v tomto smyslu měla vztahovat povinnost školní docházky na tři, čtyři, šest nebo osm let v jediném typu školy. Zavedení alespoň čtyřleté základní školy se nakonec podařilo parlamentární cestou po skončení první světové války a zániku monarchie (Geißler, 2013, s. 384-446). Soukromá i veřejná školní zařízení nižšího stupně, jež při obcházení povinnosti docházky do obecné školy zajištovala přípravu dětí k přechodu na gymnázium, byla sice postupně rušena, devítiletého gymnaziálního studia, kam děti nastupovaly v jedenácti letech, se však tato opatření nedotkla. K rozhodování o volbě a výběru vzdělání, zatíženému 
nejrůznějšími sociálními a pedagogickými aspekty, tak dál docházelo velmi časně a v neprospěch těch dětí, jejichž možnosti domácího vzdělávání byly pouze omezené. Otázka, jak a jakou cestou zlepšit u těchto většinových školáků šanci na vzdělání v rovině školského systému, zůstávala nevyřešena.

V levicovém politickém táboře, mezi dělnictvem a také mezi učiteli národních škol však existovala vyšší očekávání. Jejich sociálně a pedagogicky motivovaným přáním bylo ponechat pro rozhodování o volbě školy větší časový prostor. Výuka dívek a chlapců měla být společná a děti v ní neměly být rozdělovány podle církevní př́slušnosti. Náhled těchto skupin na soukromé školství byl kritický. Úkolem „lidově demokratického státu“ bylo z jejich pohledu otevř́t „pro všechny děti všechny možnosti vzděláni““. Autorství některých sociálních a pedagogických zlepšení si v tomto smyslu připsala Sociálnědemokratická strana Německa (SPD) založená v roce 1863, a to především na komunální úrovni a v částech Německé říše, jako byl Hamburk, Braunschweig a Sasko. Komunistická strana Německa (KPD), která vznikla z SPD v roce 1919/1920, stála v Říšském sněmu v opozici a ve své každodenní politice se držela tradičních zásad politiky vzdělávání. Chtěla je však uskutečňovat podle sovětsko-ruského vzoru a především v budoucím „sovětském Německu“. Škola se tak měla stát strukturálně ,jednotnou“, měla být propojena s prací ve „výrobě“ a marxismus se v ní měl stát světonázorovým základem veškeré výuky a výchovy.

Přes tyto a všechny další rozdíly si představy sociálních demokratů a komunistů (tedy zejména těch, kteří byli aktivně činní v oblasti politiky vzdělávání, a pedagogů) byly v tom zásadním společné. To platilo i v době národního socialismu. Tyto jejich myšlenky se po skončení války v roce 1945 staly za podpory vojenské moci v sovětské okupační zóně (SBZ) politicky rozhodujícími. Ve východoněmeckém státě Německé demokratické republice (DDR) vzniklé v říjnu 1949 byly následně autoritativně politicky využívány.

\section{Rozhodnutí 1945 až 1949}

Rámcové podmínky školství (Anweiler, 1992) zakotvil v květnu/červnu 1946 „Zákon k demokratizaci německé školy“ (Tenorth, 2011). Jeho 
autorství patřilo skupince školských odborníků, jíž se touto cestou podařilo prosadit své reformní představy, jež ve Výmarské republice (1918-1933) v podstatě neměly šanci na uskutečnění (Geißler, 2017). V závislosti na politickém zázemí zúčastněných představoval zákon navázání na požadavky vzdělávací politiky z času listopadové revoluce 1918/1919 nebo krok k řešením, která by byla slučitelná s orientací sovětské školy. Komunisté do programu právní reformy, kterou politicky podporovali, nevnesli téměř žádnou vlastní myšlenku. Obnovenou otázku propojení výuky s produktivní prací ze sovětské školy 30. let 20. století zákon neřešil. V částečně plánované volitelné výuce vyšších ročníků všeobecně vzdělávací školy však byla reformní pedagogická myšlenka pracovní školy stále rozpoznatelná.

Nově zavedená povinná osmiletá a koedukativní základni škola zaručovala „stejné právo na vzděláni““ „všem mladistvým, dívkám i chlapcům, dětem z měst i venkova " bez ohledu na majetkové poměry rodičů a nezávisle na „vyznáni““ a „původu“. Na základní školu navazovala učiliště a odborné školy. Maturita opravňující k zahájení studia na vysoké škole bez dalších zkoušek byla zachována. Maturita představovala završení vyšší školy (Oberschule), která byla zkrácena na čtyři roky a předcházela jí škola základní. Stejně jako v dříve používané typové diferenciaci i nyní existují tři specializované směry gymnázií (moderní jazyky, přírodní vědy, staré jazyky). Vedle ruštiny, která se vyučovala již od 5. třídy základní školy, zůstala ve větvi klasických starých jazyků povinným předmětem latina. Ta se na několika málo školách spojených s Oberschule vyučovala již od 7. třídy.

Výuka náboženství už sice nebyla součástí učebních osnov, církve však směly ke své výukové činnosti využívat prostory základních škol před hlavním vyučováním a po něm. Prvky církevního školství se udržely i v řadě dětských domovů a mateřských škol. Soukromé školy naopak povoleny nebyly.

Pokud jde o - z velké části nové, mladé a jen provizorně vyškolené - učitele nastupující po završení rázných denacifikačních opatřní, ti měli zpočátku v uspořádání své výuky značnou volnost. Pro vedení škol šlo beztak v první řadě o to, aby se výuku vůbec podařilo obnovit. Netrvalo však dlouho a do úředních plánů a metodických 
pokynů k jednotlivým výukovým předmětům byly zařazeny konkrétní a podrobné instrukce a učební látka byla jasně uspořádána. Neustále rostoucí zastoupení sovětských autorů v odborné literatuře současně napovídalo o ještě zřetelnější změně orientace. Vzor mezitím už nepřetržitě vedené a přísně regulované „sovětské školy“, který se utvářel radikálním odklonem od západní reformní pedagogiky od začátku 30. let 20. století, se začínal prosazovat. Dle dobových tvrzení se tato škola měla ponaučit ze západoevropsky inspirovaných pokusů a omylů 20. let 19. století (Konstantinow, 1948).

\section{Reforma školství a politický režim}

V srpnu 1949 se novými směrnicemi přihlásila k moci ve školské politice Jednotná socialistická strana Německa (SED). Strana vznikla v dubnu 1946 jako výsledek do značné míry násilného sloučení sociálnědemokratické (SPD) a komunistické (KPD) strany Německa. Nové směrnice zahrnovaly především projekty, jejichž konfliktní uskutečňování rozhodlo o dějinách školství na několik prríštích let a za jejich horizont (Geißler, 1992).

Spolu s „rozvojem politicky uvědomělých a odborně vysoce kvalifikovaných učitelů a vychovatelư “ měla být do všech stupňů vzdělávání zařazena změna výukových a výchovných obsahů ve smyslu SED. Mateřská škola měla ztratit svůj charakter sociální péče a stát se „organickým předstupněm školního vzděláváni“. Od základní školy se očekávalo „pozvednutí všeobecné úrovně vzdělanosti ve městě a zejména na venkově“, od odborných škol zase to, že významně přispějí ke „Zvyšování produktivity práce“. Vyšší škole bylo uloženo sloužit k „přrípravě a výchově nové demokratické inteligence“. Pro dosažení těchto cílů se počítalo se změnami nejen v rovině výukového obsahu, ale také ve „složení učitelských sborư“. Všichni učitelé a vychovatelé byli vyzváni, aby se vzdělávali v marxismu-leninismu a rozvíjeli a upevňovali „přátelství se Sovětským svazem“.

Po zavedení reformy školství, která měla usilovat o „demokracii“ a společenskou otevřenost, tak rychle získaly na váze principy školské politiky a pedagogiky, jež v Sovětském svazu 30. let 20. století sehrály určující roli (Helmert, 1994) především z hospodářských důvodů 
a ve válečných letech pak i z důvodů sovětského vlastenectví a disciplíny. V Německé demokratické republice byl význam těchto principů umocněn navíc příchodem studené války.

\section{Koncepce výuky}

Základní škola s povinnou docházkou pro všechny vyvolala potřebu vypracovat zcela nový plán výuky a nový didaktický koncept, který by umožňoval dosažení takové úrovně vzdělání, jaká je předpokladem k přechodu na vyšší školu po osmi letech společné výuky. $Z$ toho vyplývalo systematické, předmětové vzdělávání a promyšlené, plánovité a rychle postupující vedení výuky. Znamenalo to jednak odvrat od obsahů a postupů masově lidového vzdělávání, jak bylo praktikováno doposud, jednak i zpočátku př́ikré odmítání reformních vzdělávacích koncepcí uplatňovaných ve Výmarské republice jako „školy práce“ v protikladu ke „škole indoktrinující“ (Belehrungsschule). K tomu se připojil i z hlediska rekonstrukce země silně ekonomický zájem na „zvyšování výkonnosti“ ve škole. Její dosažení bylo z pohledu aktérů školské politiky možné jedině posílením pedagogických principů a technik tradiční školy zaměřené na vzdělávání a dosahování výkonů a jejich provázáním s principy a technikami školy sovětské. Na těchto základech vznikla škola ve svých pedagogických poměrech socialisticky-konzervativní, jež byla prostřednictvím doktríny třídního boje otevřeně využívána jako politický nástroj.

Ve školním roce 1951/52 nastává ve všech sférách národního vzdělávání období rozkvětu „studia sovětské pedagogiky“ organizovaného na všech školách. Tento rozkvět však neměl dlouhého trvání. Stěžejními body uvedeného studia byla školní pedagogika, obecná didaktika a metodika jednotlivých výukových předmětů včetně „vedoucí role učitele“. V praxi se jednalo o určité typy výukových hodin, kontrolu výkonu žáků pomocí zkoušek, „kolektivní výuku“, utváření „vědomé kázně“, „uvědomělost a aktivitu“ žáků a navíc o určení vztahu mezi dědičností a prostředím.

O prosazování opatření školské politiky se starali pracovníci centrálně uspořádané státní školské správy, téměř všichni organizovaní v SED. Na jednotlivých školách existovala vedle toho přímá politická 
a ideologická kontrola ze strany školní stranické organizace. Ta se ukazovala jako nejúčinnější tam, kde byl ředitel státní školy současně i stranickým tajemníkem SED nebo kde stranický tajemník SED vykonával funkci zástupce ředitele - a podle vzoru sovětského školství tak mohl působit jako politický komisař. Se stále houstnoucí regulací, př́ibývající kontrolou pomocí školního dozoru, za podpory stranického aparátu Jednotné socialistické strany Německa (SED) a obecně v prostředí diktátorského politického systému se podařilo zajistit pozvolné přizpůsobování školství předepsaným cílům. Ostatně vždyṫ asi třetina učitelstva byla př́ílušníkem SED. V první řadě se jednalo o takzvané „nové učitele“ (Gruner, 2000), již s vyřazením pedagogů zatížených národním socialismem museli být zpočátku vyškolováni v měsíčních kurzech. U „starých učitelư “, kteří ve službě zůstali (což byl případ hlavně pedagogů vyšších škol), se často setkávali s předsudky, a tak se SED na těchto školách nakonec nedokázala prosadit tak, jak by si přála. V ještě větším rozsahu se totéž týkalo zprvu i práce dětské a mládežnické organizace na školách. K významnému ztotožnění mezi třídou a pionýrskou skupinou a k dominantnímu postavení třídního učitele i v otázkách pionýrské organizace docházelo teprve počátkem 60. let.

\section{Krize systému 1952/53}

S rozhodnutím vedení SED o dalším budování „socialismu“ bylo od poloviny roku 1952 zahájeno zavádění celé řady nových opatření. Ta zasahovala do života škol ještě větší silou. Ve středu jejich pozornosti stála zejména vyšší škola. Složit maturitu na ní hodlalo přibližně 15 \% studentů a studentek dané věkové skupiny, tedy mnohem víc, než tomu bylo $\mathrm{v}$ předchozích desetiletích. Na vyšších školách sice už v té době platila politická a společenská kritéria výběru, s jejichž pomocí se podíl dětí z rodin „dělníků a zemědělcư “ rozrostl na více než jednu třetinu, z pohledu vedení SED to však k přípravě budoucích státotvorných elit nebylo dostatečné.

S postupujícím ideologickým a organizačním pronikáním do škol se tak rodily úvahy o zavedení strukturálních změn. Zvažovala se možnost nahradit základní a vyšší školu jednotnou školou desetiletou 
a tu v budoucnu přeměnit ve školu povinnou. Jednotná desetiletá škola měla analogicky k nejvyššímu, ale nepovinnému stupni „sovětské školy“ umožňovat bezprostřední přechod na „technické a další vysoké školy“. Co se tím sledovalo, bylo jednak uvolnění finančních prostředků v napjaté rozpočtové situaci způsobené na prvním místě dalšími výdaji na armádu, jednak a především však měla být razantně oslabena stále ještě významná reprodukční základna měštanstva ve školách. Ostatně už na jaře 1953 se na vyšších školách začalo s vylučováním studentů, kteří se angažovali v církevní práci, a docházelo zde k propouštění mnoha učitelů.

Proti plánovanému projektu vedení SED však stála řada věcných úvah. Tak třeba ministerstvo národního školství upozorňovalo v první řadě na to, že desetiletá škola nebude „zprvu“ schopna zajistit potřebné kvalifikační podmínky pro přechod na vysoké a odborné školy. Kompromisní řešení přinesla vyhláška z května 1953, která stanovila, že se začátkem nového školního roku v září dojde ke sloučení desetiletých škol, otevřených v několika ojedinělých případech v období od roku 1950, a vyšších škol, vycházejících z dosavadní základní školy, do tříleté „vyšší školy nového typu“.

17. června 1953 vypuklo v NDR povstání proti vládnoucímu režimu SED, bylo násilně potlačeno. Plánovaná strukturální opatření byla v zájmu zmírnění napětí také ve školství okamžitě stažena. Tím skončilo období bezprostředního a co možná všeobjímajícího následování vzoru sovětské školy (Lost, 2000). V některých pododvětvích však přesto zanechalo trvalé stopy. Řeč je např. o rozvoji speciálních sportovních, hudebních, př́rodovědných a matematických škol, stejně jako škol s rozšířenou výukou ruského jazyka nebo o budování sítě mimoškolních zařízení, jež doplňovala vzdělávací nabídku všeobecně vzdělávací školy pomocí řady nevýukových pracovních společenství. Zásadní shoda existovala i ve věci řízení školství, vedení a utváření výuky a obecně ve všech podstatných pedagogických otázkách.

\section{Reformní úvahy}

Po systémové krizi roku 1953 následoval trend politické liberalizace, z něhož nakonec vzešla diskuse, jež byla zčásti vedena veřejně. 
Existovaly různé úvahy, zda ve prospěch diferenciace nezměnit strukturu školství a částečně také přechod na vyšší školu už před 8. třídou. Vznikají snahy o revizi konceptu učebního plánu a zlepšení výuky, která dle interního hodnocení vykazovala nedostatek metod, problémy s kázní a nedostatečné pedagogické vztahy.

V návaznosti na 20. sjezd Komunistické strany Sovětského svazu v únoru 1956, odsouzení kultu Stalinovy osobnosti v SSSR, politické změny v Polsku, a zejména v Mad’arsku, se objevovaly ve vedení SED nejistoty a názorové rozdíly také $v$ otázkách školské politiky. Tak došlo $\mathrm{k}$ tomu, že rozhodnutím vlády z března 1956 bylo na období do konce roku 1965 vyhlášeno „celoplošné zavedení škol s desetiletou docházkou“, stranické vedení SED však na ně zpočátku nekladlo téměř žádný dưraz. $\mathrm{Na}$ desetiletou školu přecházelo $\mathrm{v}$ prvním období z 8 . třídy necelých 15 \% žáků a žaček. Zatímco v odborných kruzích existovaly spory o tom, zda všeobecná reforma nemá usilovat o určitou soudržnost se sociálnědemokratickými reformními představami Západního Německa jako eventuální projev celoněmecké perspektivy (Dudek, 1993), odpovědní činitelé z ministerstva národního školství se k otázce dalšího rozvoje desetiletých škol stavěli zdrženlivě. I oni totiž stejně jako mnoho dalších členů SED na rozdíl od ostatních zemí východního bloku předpokládali, že „období přechodu k socialismu“v NDR bude prodlouženo.

$S$ tím vším získávala na pozornosti pedagogizace výuky. Současně s ní se projevil význam emotivujících forem politické výchovy, která byla nyní označována jako vlastenecká. Výuková práce se měla stát rozmanitější a živější. Učitelé byli navíc osvobozeni od povinnosti předkládat třídnímu učiteli své plány a písemné př́ípravy výuky. Obsahy učiva, které při dané výukové praxi zjevně neodpovídaly schopnostem dětí, byly bud' vypuštěny, nebo převedeny do vyšších ročníkư. A stejně jako $\mathrm{v}$ hospodářství a v jednání státu, také zde začalo hledání účinných forem kontroly ze strany státu. Ředitelům škol se dostalo vyšších rozhodovacích pravomocí. Kompetence, které byly doposud vyhrazeny ministerstvu, přešly na podř́izené subjekty a na komunální úroveň. Práci škol nová situace v mnoha případech neprospívala. Orgány místní správy totiž nově získané možnosti využívaly a zaměstnancům škol přidělovaly úkoly, jež se školní prací nesouvisely, zejména při sklizních. 
Období politického lavírování skončilo poté, kdy volby do západoněmeckého Spolkového sněmu v říjnu 1957 dopadly ve prospěch CDU/ CSU, a nikoli SPD. V tuto chvíli byla spuštěna kampaň takřka proti každému jedinci, jenž ve vedoucí pozici na ministerstvu školství nebo jako pedagogický vědec neprojevil pro zavádění desetileté školy rozhodnou podporu, vyslovil se pro větší volnost v utváření učebního plánu a výuky, pro redukování obsahů nebo pro určité oslabení ideologizace a dopustil určitý vývoj věcí. Postiženi byli hlavně pedagogové a funkcionáři, jejichž osobnosti se utvářely v reformním a socialistickém hnutí Výmarské republiky a kteří si zachovali jistou nezávislost a kritický pohled. Na jejich místa nastupovala mladá nomenklatura funkcionářů dosazených na základě dosavadní loajality a především podle toho, jak se „osvědčili“ 17. června 1953.

\section{Zavedení polytechnické vyšší školy}

Výrazem nové orientace školské politiky se stal „Zákon o socialistickém vývoji školství v Německé demokratické republice" z prosince 1959. Nový zákon na druhý pokus přinesl odtržení od „antifašisticko-demokratické školské reformy 40. let. Vedení SED v tuto chvíli sledovalo celospolečenský záměr dovést „socialistické výrobní vztahy k vítězstvi“" spolu s pokračující kolektivizací v zemědělství a znárodňováním průmyslu.

Jako základ příštího školského systému byla v zákoně stanovena povinná desetiletá všeobecně vzdělávací polytechnická škola. Protože měla poskytovat kvalitativně vyšší vzdělání, dostalo se jí pojmenování „vyšší škola“ (Oberschule) (POS). Reforma se rozšírilia i na venkově, a tak mohly od roku 1964 desetiletou školou procházet především nově zapsané ročníky dětí. Dřívější vyšší škola, nyní označovaná jako „rozšířená vyšší škola“ (EOS), s přechodem po 8. třídě a rozdělením do tří větví, byla provozována i nadále.

Nejvýznamnější změnou v koncepci školy bylo zavedení polytechnické výuky (Tietze, 2012) na začátku školního roku v záŕí 1958. Na každého žáka a žákyni 7. a 8. tříd základní školy se tím vztahovala povinnost absolvovat jeden výukový den týdně v učebních dílnách státního průmyslového nebo zemědělského podniku. Od 9. třídy se $\mathrm{v}$ tomto výukovém dni stř́ídaly vždy po týdnu jednou čtyři hodiny 
dílenské praxe ve výrobě, jednou odborná teoretická výuka se zaměřením na technologii a podnikovou ekonomii. Oproti dřivějším úvahám se tak podařilo vytvořit nejenom vědeckoteoretické, ale i produktivně praktické propojení s pracovním světem. Ve světě reálného socialismu toto propojení vyústilo v takřka současné zavádění vlastních anebo sdílených školních výrobních dílen. Školní vzdělávání a výchova tak byly provázány s prostředím podnikově sociálního zkušenostního prostředí, v němž byly v závislosti na podmínkách konkrétní školy přítomny dobově příznačné, „moderni““ výrobní procesy. Z hlediska školské politiky i organizace to byl odvážný a z pohledu tradičního chápání škol současně také vysoce inovativní krok. Od osvědčených forem rané odborné př́pravy $\mathrm{v}$ rámci povinné výuky z počátku 60 . let bylo v polovině 60 . let znovu upuštěno. Polytechnická škola zůstávala součástí všeobecného vzdělávání.

„Zákonem o jednotném socialistickém vzdělávacím systému“ zasáhla normalizace v únoru 1965 nakonec nejen školu, ale i veškerou institucionální oblast vzdělávání, a to počínaje zařízeními předškolní výchovy až po univerzity a vysoké školy, včetně zařízení odborné přípravy a dalšího vzdělávání (Zymek, 2019). Vývoj nastavenýv roce 1959 od osmileté školy k povinné desetileté docházce byl stvrzen.

V následujících letech docházelo k celoplošné transformaci dosavadní základní školy na desetiletou všeobecně vzdělávací polytechnickou vyšší školu (POS), jež nahrazuje i tradiční systém venkovských škol. Přes veškerou politickou kritiku systému a řadu individuálních obav se transformace setkávala s pozitivním zájmem i v západoněmeckých odborných kruzích, ačkoli na druhé straně budila obavy z tzv. „soutěžení systémư“. Propaganda v NDR hovořila o „převaze socialismu“, jež se nyní projevila i v oblasti vzdělávání. Cíl poskytnout desetiletou školní docházku všem dětem už do roku 1964 a zastínit v soutěžení mezi Východem a Západem školský systém Spolkové republiky Německo (Droit \& Rudloff, 2018), který dle posudku západoněmeckých odborníků stál beztak na okraji vzdělávací katastrofy, se ukázal jako přehnaný. Pokračovat ve školní docházce po 8. třídě a možnost uzavřít desetiletou školní docházku se tak pro všechny děti stalo pravidlem teprve počínaje ročníky zapsanými přibližně od poloviny 60. let, a tedy 
přibližně o deset let později. K tomuto stavu přispěla skutečnost, že stále více učebních oborů, a nakonec vlastně všechny, vyžadovaly ukončení polytechnické vyšší školy (POS).

S postupným zaváděním nových učebních plánů získala POS jednotnou a souvislou strukturu učiva od 1. až do 10. třídy. Jako právní základ výuky vznikal z postupně zaváděných učební plánů pro POS jeden „ucelený učební plán“, v němž všechny vyučovací předměty na sebe navazovaly a byly spolu odladěny napříč deseti ročníky. Nově byl přidán politicky a ideologicky mimořádně nasycený vyučovací předmět občanská nauka pro 7. až 10. třídu. Materialistický světonázor našel své místo mimo jiné i v předmětu astronomie pro 10. třídy.

Od 5. třídy byla výuka svěřena do rukou učitelů, kteří po maturitě absolvovali zpočátku čtyři a od roku 1982 pět let studia na vysokoškolských institucích, vždy se specializací na dva vyučovací předměty. Třídní skupiny na POS zůstaly z velké části zachovány až do závěrečných zkoušek a rozhodování o cestě dalšího vzdělávání bylo odloženo na raný věk dospělosti. Rodiče se tak nemuseli zabývat systémovými otázkami hierarchie škol a jejich děti tím nemusely procházet.

Téměř všichni absolventi POS, kteří nezvolili studium na některé z institucí dalšího vzdělávání, nastoupili na většinou dvouleté, někdy i tříleté odborné učiliště. Prodloužení povinné školní docházky na deset let obecně umožnilo zkrátit dobu profesní přípravy $\mathrm{v}$ učilištích, a tak se věk nástupu do zaměstnání v těchto př́padech nadále pohyboval na úrovni 18 let.

Kdo 10. třídu nedokončil, byl pro následnou přípravu na zaměstnání směřován do pevně definované skupiny méně náročných kvalifikovaných profesí. Pokud žák ani přes opakování ročníků nedokončil 8. třídu, zbývala učňovská příprava v některé z dílčích oblastí těchto oborů. Efekt takového vzdělávání spočíval nakonec mimo jiné v tom, že tito lidé dál podléhali kontrole ze strany vzdělávací instituce, a nezačali okamžitě vykonávat - jako tomu v minulosti bývalo - nejrůznější většinou střídavé a často i jen občasné práce mimo působnost všech vzdělávacích norem. Mladílidé s tělesným handicapem se na vhodné povolání připravovali ve speciálních školách s podílem odborné profesní přípravy nebo ve speciálních odborných učilištích, eventuálně stejně 
jako žáci s mentálním postižením získali jen vzdělání pro výkon jednoduchých pracovních činností. Pokud to jejich postižení umožňovalo, žáci speciálních školních zařízení mohli dosáhnout požadovaného stupně vzdělání pro vstup na vysokou školu.

V posledních letech trvání NDR se nedokončení 10. třídy týkalo jen asi jedenácti procent dětí zapsaných v daném ročníku ke školní docházce včetně žáků „pomocných a speciálních škol“. Vztaženo na žákyně a žáky - těch, kteří nedosáhli cíle dokončit 10. třídu, bylo méně než $10 \%$. Byli to především mladiství, kteří někdy i dvakrát opakovali ročník, a převážně chlapci ukončující školní docházku na úrovni 8. a občas 9. třídy. Vždy se našly školy, kde se nejrưznější problémy množily do té míry, že zde oproti doktríně školské politiky vznikaly „pochybnosti o dosažitelnosti všeobecného vzdělání pro všechny děti“, a přibývalo v nich př́ípadů předčasného ukončení školní docházky.

Nejvýznamnějším místem odborné přípravy na budoucí povolání v 60. letech 20. století byl státní prưmyslový podnik s integrovaným odborným učilištěm. Tyto školy nabízely pod jedním vedením kombinaci všeobecně vzdělávacích a odborných předmětů včetně odborné praxe, na niž dohlíželi mistři odborného výcviku. Obecní odborná učiliště poskytovala vzdělání v řemeslných a zemědělsko-zahradnických oborech a u speciálních profesí přebírala od průmyslových podniků teoretickou př́ípravu učňů. Soukromé firmy se po rozsáhlé likvidaci soukromého hospodářského sektoru od 60. let na vzdělávání dál nepodílely, a to ani ve speciálních řemeslech. Odbornými učiteli kritizovaná, ale vcelku sotva řešitelná byla praxe zařazovat odbornou praktickou výuku do plnění státního plánu podniků, protože s sebou nesla obcházení požadavků školního učebního plánu.

Na rozdíl od polytechnických vyšších škol, jejichž výuka až do podzimu 1989 probíhala šest dnů v týdnu, byl na odborných učilištích koncem 60. let zaveden týden pětidenní. Všeobecným vzdělávacím předmětům a odborné teorii byly na všech odborných učilištích věnovány dva nebo tři dny výuky v týdnu. Každý mladý člověk, který nepřestoupil na maturitní stupeň nebo na odbornou školu pedagogického, zdravotního nebo uměleckého směru, získal v rámci stávající povinnosti odborné prúípravy na povolání učňovské místo. Tomu předcházel nábor do odborných 
učilišt, který se řídil všeobecným stavem poptávky na úrovni národního hospodářství vcelku a regionálně. Přístup ke vzdělání podle svých představ však získala pokaždé jenom část zájemců. Nebyl to výsledek anonymního řízení trhu, nýbrž státního zájmu. Vzhledem k tomu, jaké byly záruky pozdějšího získání pracovního místa, jež by odpovídalo dosaženému vzdělání, držela se motivace k učení na odborných učilištích a hlavně ve všeobecně vzdělávací části u většiny učebních oborů na poměrně nízké úrovni.

Od dřivějších politicky motivovaných plánů a představ zpřístupnit vysokoškolské a odborné technické studium v budoucnosti především po absolvování odborného učiliště a vychovávat tak „jádro nové inteligence“ z „dělnické třídy“, bylo upuštěno již počátkem 60. let. Převládající cestou tak byla rozšířená vyšší škola (EOS). Novinkou v dějinách vzdělávání se stala možnost získat kvalifikaci pro vstup na vysokou školu nebo všeobecné plnohodnotné odborné vzdělání pro profese, jejichž nabídka nakonec zahrnovala 86 oborů, po ukončení polytechnické vyšší školy tříletou nástavbou ve speciální „maturitní třídě“ na některém ze státních středních odborných učilišt. Ke studiu „učebního oboru s maturitou“ (BmA) (Drechsel, 1996) - zpočátku jen pokusně zavedenému v roce 1959 - se hlásili hlavně ti žáci a žákyně, kteří z nejrůznějších dưvodů nepřestoupili z 8 . třídy na rozšírenou vyšší školu. Učební plány a učebnice rozšířených vyšších škol byly sice pro učební obor s maturitou od školního roku 1969/70 závazné, hudební výchova a výtvarná výchova se v nich však nevyučovaly (nebo nebyly povinné), a tak maturita na BmA nedosahovala stejné společenské prestiže jako klasické maturitní vzdělání. Pro přijetí na vysokou školu to však nehrálo významnou roli. Oproti absolventům EOS měli absolventi učebních oborů s maturitou naopak tu výhodu, že v případě nepřijetí na vysokou školu, nebo pokud se mezitím změnila jejich životní situace nebo se případně rozhodli pro jinou profesi, jako kvalifikovaní pracovníci měli v hospodářství výhodné možnosti získání zaměstnání. A další návštěvou technických škol či v rámci vzdělávání dospělých si mohli zajistit rychlý další rozvoj. 


\section{Plánování školství a přístup ke vzdělání}

V otázce př́istupu k získání kvalifikace pro vstup na vysokou školu a k VŠ studiu nastal zásadní střet zájmů mezi školním vzděláváním, odbornou přípravou a státem zaručovaným právem na zaměstnání. Počet absolventů vysokých škol a studia technického směru se v 60. letech ztrojnásobil. Ještě v roce 1969 plánovala strana ve svém usnesení zvýšit počet vysokoškolských absolventů působících v ekonomice tak, aby odpovídal „nejvyšší světové úrovni“. Brzy se však ukázalo, jak málo je tento plán slučitelný se skutečnou hospodářskou dynamikou tehdejší NDR. Od té chvíle probíhaly snahy vyladit výkony školství s předpokládanými potřebami kvalifikovaných sil, a to jak celospolečensky, tak v konkrétních profesních skupinách. Na první příčku zájmu se dostala příprava v odborných učilištích, zatímco přístup na rozšířené vyšší školy (EOS) a vysoké školy byl řízen restriktivním způsobem.

Podíl maturantů ze všech typů škol, které zajištovaly přípravu k získání kvalifikace pro vstup na vysokou školu, byl v jednom ročníku po desítky let i po skončení války přibližně na úrovni $3 \%$. Nejvyšší hodnoty dosáhl v roce 1973, aby v roce 1980 poklesl na $12 \%$, a v dalších letech (při zahrnutí absolventů učebních oborů s maturitou) se pohyboval kolem $14 \%$ a méně.

Omezení přístupu na rozšířené vyšší školy vedlo mezi uchazeči k ostré konkurenci. Přibližně od počátku 70. let jejich okruh výrazně přesahoval plánovaný kontingent přijetí na EOS (cca 10 \%) i na odborná učiliště s maturitou (cca $5 \%$ ) a dál se nepřetržitě zvyšoval. Neustále rostl podíl žáků, kteří zakončili polytechnickou vyšší školu (POS) se známkou „s vyznamenáním“ a „velmi dobře“, a to vzhledem $\mathrm{k}$ trendu méně přísného hodnocení výkonů. Zatímco ve školním roce $1959 / 60$ tento podíl ještě představoval 5,6 \% a v roce 1970/71 byl kolem $8 \%$, v polovině 80 . let zakončilo docházku na POS „s vyznamenáním“ kolem 10 \% a se známkou „velmi dobře“ to bylo něco přes 14 \% žáků POS.

V přijetí na rozšířené vyšší školy nebo odborná učiliště s maturitou, jež pro 7. třídu znamenalo nutnost účasti na volitelném předmětu v některém $\mathrm{z}$ druhých cizích jazyků, získávalo prioritu vedle učebních výkonů a splnění určitých politických minimálních standardů, jako bylo členství ve státní mládežnické organizaci, i co možná vyvážené 
zastoupení obou pohlaví a především pak uvedené přání budoucího povolání anebo studia. Mimořádný zájem byl o budoucí „lampasáky“ (studenty důstojnických vysokých škol). Z propagandistických důvodů a v rámci „diferencované“ politiky ve vztahu k církvím se však dbalo na to, aby byl do škol přijímán i určitý počet uchazečů z rodin farářů (Ernst-Bertram \& Planer-Friedrich, 2013) a církevních hodnostářů, projevujících dostatečnou loajalitu systému. V podstatě žádnou šanci naopak neměli ti, kteří viditelně odmítali věrnost státní doktríně nebo pocházeli z politicky poznamenaných rodin. Ti poslední, vědomi si své situace, v některých př́ípadech na podání žádosti k přijetí na školu dokonce předem rezignovali. Období, v němž se prostřednictvím školského systému privilegovaně dostávaly na vedoucí pozice ve společnosti „děti z dělnických a rolnických rodin“, se blížilo ke konci. V podobě „socialistické inteligence" mezitím vznikla nová společenská vrstva lidí s vysokoškolským nebo technickým vzděláním. V posledních deseti letech existence DDR patřil do této třídy přibližně každý čtvrtý výdělečně činný jedinec. A právě rodiče náležící $\mathrm{k}$ této třídě dokázali v př́ípadě, že jejich děti nebyly na rozšírenou vyšší školu přijaty, zajistit pro ně přijetí dodatečně. Předčasný odchod z EOS nebo odborných učilišt s maturitou stejně jako nesložení závěrečné zkoušky byly výjimkou. Opakování ročníku bylo vyloučeno, jen občas docházelo k opakování zkoušek. Kdo jednou dosáhl maturity, ten v 70. a 80. letech zpravidla navázal vysokoškolským studiem.

\section{Diferenciace struktur školských systémů}

Původní rozdělení do tří větví nahradily od konce 60. let 20. století na rozšířených vyšších školách (EOS) nejrůznější typy „speciálních tříd“. Tyto třídy nakonec vznikly asi v polovině škol a nabízely na jedné straně prohloubené nebo rozšířené vzdělání v určitých vyučovacích předmětech, na straně druhé byly zaměřeny na cílenou podporu vysoce nadaných žáků. Vzhledem k tomu, že přestoupení na EOS bylo po přechodných řešeních od roku 1982/83 nakonec možné jen po úplném a úspěšném završení desetileté docházky na polytechnické vyšší škole (POS), měla ted'EOS pouze dva ročníky. Takové rozhodnutí se setkávalo se skeptickým pohledem nejen ve vědeckých pedagogických kruzích, ale 
o to více mezi učiteli a obecně i v části obyvatelstva projevující zájem o školství. Rodily se obavy z poklesu úrovně maturitních zkoušek, a nejen z toho. Mezi učiteli rozšrirrených vyšších škol a v některých rodinách vznikaly obavy ze ztráty společenského postavení. Několik málo EOS si přesto coby speciální školy zachovalo čtyřletou školní docházku, tj. včetně 9. a 10. tříd. Takové školy spolupracovaly většinou s vysokoškolskými institucemi a podle svého profilu žákům nabízely intenzivnější výuku matematiky, př́rodovědných předmětů, moderních cizích jazyků nebo hudebně-výtvarných oborů. Vlastní charakter a strukturu měly sportovni školy pro děti a mládež, jejichž absolventi tvořili olympijský kádr NDR.

Zvláštní podpoře na polytechnických vyšších školách se těšily „třídy s rozšírenou výukou ruského jazyka“. Vybírány byly děti, které vykazovaly mimořádné schopnosti, a zejména ty, jejichž rodiče se zdáli poskytovat spolehlivou záruku školního úspěchu. To hlavní, co tyto školy činilo zajímavými v očích rodičů - a mezi nimi hlavně těch s vysokoškolským vzděláním, umělců anebo státních funkcionářơ, nebyla nutně vidina rostoucích jazykových schopností dítěte, ale poměrně vysoká pravděpodobnost pozdějšího přestupu na EOS. Výuka probíhala v ruštině podle zvláštních nebo jen mírně upravených učebních osnov. Ruské třídy nakonec existovaly na 160 školách z celkového počtu 5000 polytechnických vyšších škol a jejich žáci a žákyně vykazovali ve všech vyučovacích předmětech výrazně nadprůměrnou úroveň.

Jako spíše nedostatečnou lze hodnotit podporu vzdělávání pro skupinu dětí školního věku ze znevýhodněných, v důsledku biotických okolností nebo souhry nepříznivých sociálních a rodinných poměrů. Přestože pedagogové polytechnických vyšších škol i pomocných a zvláštních škol využívali nejrůznější formy podpůrných opatření, naráželi s nimi na meze převládajícího pojetí výuky a učebních osnov. Děti s mentálním či těžkým kombinovaným postižením, coby „nezpưsobilé ke školnímu vzdělávání a způsobilé pro získání podpory“, navštěvovaly stále častěji rekonvalescenčně pedagogická zařízení denní péče. Zákonná povinnost školní docházky vázaná na zakončení školy se na ně nevztahovala. Část těchto dětí byla přenechána do výhradně domácí péče, v jejímž zvládání nakonec pomáhaly samoorganizované 
rodičovské skupiny. Deficitní byla podpora zejména v nejtěžších př́ípadech (kombinovaně) postižených dětí, jež byly jako jedinci nezpůsobilí péče umistovány do psychiatrických/neurologických zařízení.

\section{Výuka}

Ačkoli byla struktura výuky z velké části pevně stanovena formou učebních osnov, učebnic, didaktických a metodických pokynů, její vlastní uspořádání nakonec stejně zůstávalo v rukou jednotlivých učitelů. Podoba výuky se odvíjela od jejich osobních a profesně odborných schopností, od stavebně-technického zázemí konkrétní školy i od jejího sociálního prostorového zasazení. A dokud se indoktrinační účinky ve světonázorově ideologické rovině nedaly zpochybnit, zůstával prostor pro další rozvoj pedagogického talentu a didaktických schopností. Děti a mladiství se tak setkávali s učiteli, kteří svou výuku ztvárňovali přitažlivým způsobem, živě, různorodě a se zaměřením na konkrétní problém. Stejným způsobem tito učitelé dokázali pojmout a uplatnit svůj výklad učiva, heuristický rozhovor a diskusi a v některých, spíše ojedinělých př́ípadech, i kooperativní práci žáků. Zařazována byla žákovská cvičení a také exkurze. Vybavení škol a využívání médií, tedy minimálně vybavení mediální technikou, odpovídalo co možná nejvíce aktuálnímu stavu. Televize začala vysílat ve vyučovacím čase speciální programy ke konkrétním předmětům.

Výuka s individuálními výukovými programy a akceptace zvláštních cest osvojování učiva existovaly jen ve speciálních školách a speciálních třídách. K tomuv 70. letech 20. století přibyly pro 9. a 10. třídy polytechnických škol nepovinné „pracovní skupiny dle rámcového programu“. Jejich počet v závěru vzrostl na 22 skupin. Jednalo se o odpolední činnost v rozsahu dvou hodin týdně, do níž se zapojovali především žáci se zájmem o přestup na rozšířenou vyšší školu. Skutečného významu dosáhly tyto rámcové programy upravené na potřeby malých učebních skupin teprve na samotných EOS. K prolomení poměrně strnulého konceptu zprostředkování vědomostí a jejich osvojování, jak ho obhajovala školská politika, však nevedly ani školní experimenty, ani rozsáhlý empirický výzkum výuky, který zahrnoval téměř všechny předměty a formy škol, ani přepracování učebních plánů. Didakticky diferencovaná a na 
dělbě práce založená výuka, která by byla přizpůsobena individualitě konkrétního jedince, tak zůstávala pouhou deklarací - ambicí teoretiků výuky, jejíž uskutečnění bylo na pozadí požadavků státu a neustále se opakujících politických zásahů do výzkumu sotva možné.

Ve školní praxi tak už vzhledem k setrvačnosti tradičních vyučovacích metod převládala obecně „frontálni“", tzn. na učitele soustředěná a zároveň i kognitivně náročnější výuka, jež se s různou mírou úspěšnosti snažila vyhovět úředním požadavkům učebních osnov. Rozhodujícím kritériem při posuzování výkonnosti učitelů dál zůstávala „věrnost učebním osnovám“. Prostor pro ztvárnění výuky tak zůstával otevřený novým myšlenkám jen do té míry, dokud nebyly zpochybněny zásady školské politicky a teorie vyučování poplatné 50. letům.

\section{Provoz škol}

Poté, co bylo v polovině 60 . let 20. století rozhodnuto v základních otázkách koncepce školství a od 13. srpna 1961 byl občanům NDR a učitelưm znemožněn útěk anebo odchod do zahraničí, začal mít chod škol stále plynulejší charakter. Výuka probíhala stále častěji ve školních budovách srovnatelné velikosti. Školy na venkově měly při vybudované školní síti často po jedné třídě v každém ročníku, školy s 500 až 600 místy mívaly většinou v každém ročníku třídu $\mathrm{A}$ a $\mathrm{B}$ a působily v blízkosti místa bydliště svých žáků. Vzhledem k počtu učitelů, který se pohyboval mezi 40 až 50, a při celkovému počtu 20 až 30 tříd po přibližně 25 žácích byl takový systém přehledný a jeho řízení včetně školní družiny pro žáky 1 . až 4 . tř́íd dobře zvládnutelné.

Učitelské sbory byly personálně poměrně stabilní. Noví učitelé mezitím získávali průpravu v teoretických částech „marxisticko-leninské pedagogiky“ a jejich dílčích disciplín způsobem co nejbližším školní praxi a odborně vědeckému pojetí. Jejich chování v mocenském poli vzdělávací politiky a pedagogiky reálného socialismu sahalo podle individuálního postoje od politicky pedagogické angažovanosti přes rezervovanou profesní rutinu až po maximální nepoddajnost. S ohledem na průměrné př́ijmy pedagogů a vysokou míru mimoškolních činností při vedení kroužků a pracovních skupin, na povinnosti třídních učitelů a práci v pionýrské organizaci, straně 
a odborech a v některých případech i vzhledem k nasazení při prázdninové péči o školní děti, byly profesní požadavky stále vysoké. V učitelských sborech polytechnických a rozšírených vyšších škol se přitom neustále zvyšoval podíl učitelek, který koncem 80. let 20. století dosáhl přibližně 75 \%. Nejvyšší podíl - téměř $90 \%$ - představovaly učitelky na nižším stupni, tzn. v 1. až 4. třídách, jejichž vyučující absolvovali čtyřleté odborné studium po ukončení POS.

Vzdělávacím systémem procházelo stále více populačně slabých ročníků. Sestupnou tendenci vykazovaly absolutní počty žáků od roku 1976. Od začátku až do konce 80. let klesl nakonec počet absolventů POS téměř o polovinu. To přispělo ke snižování počtu žáků ve třídách, zatímco rozsah prípravy učitelů byl udržován konstantně stejný a vzdělávání odborných učitelů 5 . až 12. tříd se v roce 1982 rozšírilo ze čtyř na pět let. Na začátku 80. let se počty žáků ve třídách POS pohybovaly kolem 22, na EOS kolem 20, na pomocných školách kolem jedenácti a na zvláštních školách kolem devíti žáků. V posledním desetiletí existence NDR odpovídal i personál a odborní pedagogové všeobecně vzdělávacích škol, stejně jako pracovníci v předškolní přípravě, do značné míry sledovaným normám. Všichni absolventi pedagogických směrů získali zaměstnání ve všeobecném školství s plným úvazkem na 24 nebo 23 hodin týdně. Změna školy z osobních dưvodů jim alespoň v prvních třech služebních letech nebyla umožňována. Učitelské páry a svobodní absolventi dostávali přednostně umístění v okresních školách.

Výrazně upevněnou pozici v celkové státní struktuře měla od 60. let správa škol. Jako stabilní a také účinný disciplinární nástroj především pro dohled nad vedoucí činností školních ředitelů zde fungovala hierarchizovaná školní inspekce, pověřená politickou kontrolou. Radu pedagogům a hlavně začínajícím učitelům při výukové práci čas od času poskytovali okresní predmětoví poradci, kteří jejich práci také vyhodnocovali. Na všech školách existovaly školní stranické organizace Jednotné socialistické strany Německa (SED). Jejich členy byla přibližně třetina zaměstnanců POS a 70 \% zaměstnanců EOS. Až na několik málo výjimek byli v SED organizováni všichni pracovníci vedení škol. Přibližně třetinu ředitelských míst zastávaly ženy, jež většinou současně vedly i domácnost s dětmi. 


\section{Politické napětí}

Polytechnické a rozšîŕené vyšší školy obecně patřily k těm státním institucím NDR, které se zvlášṫ disciplinovaně a spolehlivě snažily podřídit všechny žáky normě kolektivní, ideologicky indoktrinující výchovy. Za tímto účelem byla škola nad rámec vyučování propojena s institucionálními a ideovými nositeli „socialistické výchovy“ např. prostřednictvím „patronátních smluv“ uzavíraných mezi školními třídami a pracovními kolektivy závodů podniků „, rukou lidu“ a zemědělských výrobních družstev. Bezprostředně svázána se školami byla činnost jednotného svazu dětí a mládeže. Státním výchovným cílům byla podřízena i činnost rodičovských sdružení. Základem veškerého vyučování byl materialistický světonázor v podobě marxismu-leninismu. I když učební program školy nebyl militantně ateistický, tradiční církevní iniciační rituály začaly být již od poloviny 50. let stále účinněji ze strany státu nahrazovány slavností „Jugendweihe“ [civilní oslavou přechodu k dospělosti]. Součástí oslav byly př́ípravné akce, pořádané každý měsíc v 8. ročnících $\mathrm{v}$ průběhu celého školního roku. K tomu se řadila i zesílená spolupráce s armádou, jež pro žáky 9. a 10. třídy polytechnických vyšších škol vyústila počátkem 80 . let ve školní předmět „výuka obrany“. Ta se konala v průběhu školního roku vždy v rozsahu čtyř dvouhodin. V červnu se navíc žáci 9. tříd účastnili „obranného výcvikového tábora“, který byl náhradou za dva týdny normální výuky. Tábor zahrnoval 12 výcvikových dnů po osmi hodinách, kdy pro žákyně platila stejná délka, a vždy šest hodin výuky „civilní obrany“.

Zejména v posledních deseti letech existence NDR však na mnoha školách zavládla politická rutina a únava. Snahy státní správy ochránit školy před tendencemi „ideologického ústupu“ projevujícími se v jiných oblastech, např. mezi „představiteli kultury“ a ve vědeckých institucích, vedly ke stále častějším konfliktům. Již od poloviny 70. let narážela státní vzdělávací politika na kritické a sebevědomé hlasy z řad obyvatelstva, jejichž odvahu posiloval proces politického uvolňování v Evropě. Tito lidé také často a vědomě využívali relativně ochranný prostor církve.

I když se mohlo zdát, že světově revoluční „charakter epochy“ byl více než dostatečně objasněn prostřednictvím výuky, teorie a školení, „základní přesvědčení o vítězství socialismu“, které mělo být nositelem 
všeho ostatního, mezi školní mládeží neustále ochabovalo a sdílela je v té době beztak už jen část mladých lidí. S výjimkou skupiny funkcionářu na plný úvazek ztrácelo členství ve státním svazu mládeže u jednotlivců téměř veškerý význam. Naproti tomu rostl počet i aktivita subkulturních skupin mládeže, $\mathrm{v}$ očích státních dozorčích orgánů „negativně dekadentních“ nebo ještě spíše „nepřátelsky negativních“. Stát ztratil schopnost vzbudit v mládeži výraznější nadšení pro štastné vidiny budoucnosti a na druhé straně nebyl ve stavu, aby úspěšně bránil mladým v touze žít podle jejich představ.

Od poloviny 80. let docházelo navíc i v prostředí pedagogů k rozrušení politických vazeb a loajality, ležících v základech státu. Šírily se nejrůznější pedagogické reformní představy (Kaack, 2016), které byly zčásti disidentské, jinak ale nadále motivované stabilizací systému. Reformní představy se objevily i v odborných pedagogických kruzích (Geißler, 2004; Tenorth, 2017), kde se dotkly v první řadě dosavadních výběrových postupů, chápání školních výsledků, uspořádání výuky a další řady témat. Vyrovnat se s takovým vývojem bylo z hlediska mocenské politiky o to složitější okamžikem, kdy se v Sovětském svazu rozběhly reformní procesy a vedení oficiální státní strany uprostřed politického dilematu a navzdory všeobecným očekáváním odmítlo vykročit stejným směrem.

\section{Literatura}

ANWEILER, Oskar, FUCHS, Hans-Jürgen, DORNER, Martina, PETERMANN \& Eberhard (eds.), 1992. Bildungspolitik in Deutschland.

Ein historisch-vergleichender Quellenband. Opladen: Leske und Budrich.

DRECHSEL, Klaus, 1996. Berufsausbildung mit Abitur - ein doppelqualifizierender Bildungsgang. In: Arbeitsgemeinschaft Qualifikations-Entwicklungs-Management: Aspekte der beruflichen Bildung in der ehemaligen DDR. Anregungen, Chancen und Widersprüche einer gesamtdeutschen Weiterbildungsdiskussion. Münster: Waxmann, s. 337-394.

DROIT, Emmanuel \& RUDLOFF, Wilfried, 2018. Vom deutsch-deutschen Bildungswettlauf zum internationalen Bildungswettbewerb. In: BÖSCH, Frank (ed.). Geteilte Geschichte. Ost- und Westdeutschland 1970-2000. Göttingen: Vandenhoeck \& Ruprecht, s. 321-368. ISBN 978-3525300831. 
DUDEK, Peter, 1993. Gesamtdeutsche Pädagogik im Schwelmer Kreis. Geschichte und politisch-pädagogische Programmatik 1952-1974. Weinheim, München: Juventa.

ERNST-BERTRAM, Bettina \& PLANER-FRIEDRICH, Jens, 2013. Pfarrerskinder in der $D D R$. Außenseiter zwischen Benachteiligung und Privilegierung. Berlin: Eigenverlag.

GEIßLER, Gert, 2013. Schulgeschichte in Deutschland. Von den Anfängen bis in die Gegenwart. 2. Auflage. Frankfurt am Main: Peter Lang. ISBN 978-3631648346.

GEIßLER, Gert, 1992. Zur erziehungswissenschaftlichen Diskussion in der DDR 1955 bis 1958. In: Zeitschrift für Pädagogik. 6, s. 913-940.

GEIßLER, Gert, 2004. Perspektivplanung im Unbewusstsein der Zeit. Überlegungen aus der Akademie der Pädagogischen Wissenschaften zur Weiterentwicklung der Oberschule im einheitlichen sozialistischen Bildungssystem der DDR vom Juli 1989. In: Jahrbuch für Historische Bildungsforschung. 10, s. 287-304.

GEIßLER, Gert, 2017. Das „Gesetz zur Demokratisierung der deutschen Schule“ in der Sowjetischen Besatzungszone Deutschlands. Administrative Verfahren und Entscheidungsprozesse (mit einem Quellenanhang: Tagung bei der SMA, Abt. Volksbildung in Karlshorst am 24. und 25. Juni 1946). In: BANSER, Günter, KIRCHHÖFER, Dieter \& UHLIG, Christa (eds.). Schulreform 1946 in der Sowjetischen Besatzungszone Deutschlands. Frankfurt am Main: Peter Lang, s. 67-131. ISBN 978-3631721346.

GRUNER, Petra, 2000. Die Neulehrer - ein Schlüsselsymbol der DDR-Gesellschaft. Weinheim: Deutscher Studienverlag. ISBN 978-3892719175.

HELMERT, Gundula, 1994. Schule unter Stalin 1928 bis 1940. Über den Zusammenhang von Massenbildung und Herrschaftsinteressen. Wiesbaden: Harrassowitz,

KAACK, Heike, 2016. Der IX. Pädagogische Kongress am Ende der DDR. Frankfurt am Main: Peter Lang. ISBN 978-3631672686.

LOST, Christine, 2000. Sowjetpädagogik. Wandlungen Wirkungen Wertungen in der Bildungsgeschichte der DDR. Baltmannsweiler: Schneider Verlag Hohengehren. ISBN 978-3-89676-272-6.

TENORTH, Heinz-Elmar, 2011. Bildungspolitische Geschichte der „Grundschule“ in der SBZ und frühen DDR, 1945/46-1951/52. In: JUNG, Johannes et al. (eds.). Die zweigeteilte Geschichte der Grundschule 1945 bis 1990. Ausgewählte und kommentierte Quellentexte zur Entwicklung in Ost- und Westdeutschland. Berlin, Münster: Lit Verlag, s. 53-79. ISBN 978-3643110879.

TENORTH, Heinz-Elmar, 2017. Die „Erziehung gebildeter Kommunisten“ als politische Aufgabe und theoretisches Problem. Erziehungsforschung in der DDR zwischen Theorie und Politik, Wissenschaftssystem und Praxis. In: Zeitschrift für Pädagogik. Beiheft, s. 207-275. 
TIETZE, Andreas, 2012. Die theoretische Aneignung der Produktionsmittel. Gegenstand, Struktur und gesellschaftstheoretische Begründung der polytechnischen Bildung in der DDR. Frankfurt am Main: Peter Lang Verlag. ISBN 978-3631639191.

ZYMEK, Bernd, 2019. Prägende Schulreformen in den beiden deutschen Nachkriegsstaaten (1955-1995). In: BREKEMEYER, Nils, BOS, Wilfried \& HERMSTEIN, Björn. (eds.). Schulreform. Zugänge, Gegenstände, Trends. Weinheim, Basel: Beltz Verlag, s. 148-177. ISBN 978-3407258205. 